\title{
Pengaruh Aktivitas Penambangan Pasir Terhadap Kondisi Sosial Ekonomi Masyarakat Di Desa Naga Kesiangan Kabupaten Serdang Bedagai
}

\author{
Galang Rasidi ${ }^{1}$, Elizon Nainggolan ${ }^{2}$ \\ ${ }^{12}$ Program Studi Pendidikan Masyarakat \\ Fakultas Ilmu Pendidikan, Universitas Negeri Medan \\ Email: Elizonain62@unimed.ac.id
}

\begin{abstract}
Abstrak
Penelitian ini bertujuan untuk mengetahui : (1) Tingkat aktivitas penambangan pasir di Desa Naga Kesiangan, (2) Tingkat sosial ekonomi masyarakat Desa Naga Kesiangan, dan (3) Pengaruh aktivitas penambangan pasir terhadap tingkat sosial ekonomi masyarakat Desa Naga Kesiangan. Penelitian ini dilakukan pada bulan Februari hingga April tahun 2020 di Desa Naga Kesiangan. Jenis penelitian ini menggunakan deskriptif korelasional. Sampel berjumlah 73 responden yang diambil dengan teknik purposive sampling. Teknik pengumpulan data menggunakan observasi, dokumentasi, dan angket. Teknik analisis data dengan uji normalitas, uji homogenitas, uji lineritas, dan uji hipotesis dengan regresi sederhana. Hasil penelitian menunjukkan bahwa: (1) Aktivitas penambangan pasir di Desa Naga Kesiangan (72,22\%) termasuk ke dalam kategori Sering, (2) Status sosial ekonomi termasuk dalam kategori sedang yaitu sebanyak (47,2\%), (3) dari hasil uji f regresi sederhana di peroleh Fhitung sebesar 14,825 dan Ftabel $(3,1338)$ dan sig. o,ooo.
\end{abstract}

Kata Kunci: Aktivitas, Penambangan, Sosial ekonomi

\section{The Effect of Sand Mining Activities on the Socio-Economic Conditions of Communities in Naga Kesiangan Village, Serdang Bedagai Regency}

\begin{abstract}
This study aims to determine: (1) The level of sand mining activity in Naga Kesiangan Village, (2) The socio-economic level of Naga Kesiangan Village community, and (3) The effect of sand mining activities on the socio-economic level of Naga Kesiangan Village community. This research was conducted in February to April 2020 in Naga Kesiangan Village. This type of research uses descriptive correlational. Samples totaling 73 respondents were taken by purposive sampling technique. Data collection techniques using observation, documentation, and questionnaires. Data analysis techniques with normality test, homogeneity test, linearity test, and hypothesis testing with simple regression.The results showed that: (1) Sand mining activities in Naga Kesiangan Village (72.22\%) were included in the Frequent category, (2) Socioeconomic status included in the moderate category (47.2\%), (3) of Simple regression $\mathrm{f}$ test results obtained Fcount of 14.825 and Ftable (3.1338) and sig. o,ooo.
\end{abstract}

Keywords: university student, online learning, education, covid 19 


\section{Journal of Millennial Community, 3 (1), March 2021 \\ Galang Rasidi, Elizon Nainggolan}

\section{PENDAHULUAN}

Perlu diketahui Di Desa Naga Kesiangan Pada Awalnya sebelum adanya penambangan pasir mayoritas masyarakat di Desa Naga Kesiangan adalah buruh tani yang dapat mengolah lahan pertanian yang cukup luas sesuai dengan kemampuan yang dimilikinya. Masyarakat petani dapat mencukupi kebutuhannya dari hasil pertaniannya. Tetapi seiring dengan perkembangan zaman dan pertumbuhan penduduk di Desa Naga Kesiangan, masing-masing petani hanya mengolah lahan yang semakin sempit. Hal ini terjadi karena lahan yang semakin lama kurang subur akibat adanya musibah hama pertanian. Ditinjau dari segi penghasilannya, dalam setahun petani hanya bisa tiga kali panen. Hasil panen satu rante rata-rata 15 sampai 20 kaleng padi. Satu kaleng padi sama dengan 10 kilogram. Sementara harga padi berdasarkan harga pasar saat ini sekitar Rp 40.000,oo sampai Rp 50.000,00 tergantung jenis padinya. Bagi yang menyewa lahan, upah sewanya dalam sekali panen senilai satu kaleng padi per rante (400 $\mathrm{mm}_{2}$ ). Jadi penghasilan petani dalam sekali panen dari hasil padi seluas satu rante sekitar Rp 600.00o,oo. Dengan demikian, dari hasil pertanian padi jelas tidak cukup untuk memenuhi segala tuntutan kebutuhannya. Sementara resiko yang dihadapi petani dalam perawatan yaitu gagal panen karena gangguan hama, banjir ketika musim hujan, kekeringan ketika musim kemarau, saluran irigasi jebol, dan lain sebagainya.

Solusi agar masyarakat menjadi mandiri dan terbebas dari kemiskinan, masyarakat harus bisa memanfaatkan sumber daya alam yang ada disekitarnya untuk memenuhi kebutuhan hidupnya. Sumber daya alam (SDA) yaitu segala sesuatu yang berasal dari alam. SDA dapat digunakan untuk memenuhi kebutuhan hidup manusia. SDA digolongkan ke dalam komponen biotik, seperti hewan, tumbuhan, dan mikroorganisme, golongan selanjutnya yaitu komponen abiotik, seperti minyak bumi, gas alam, berbagai jenis logam, air,pasir dan tanah. Kegiatan usaha penambangan pasir memberikan kontribusi terhadap peningkatan perekonomian masyarakat. Disisi lain para penambang pasir melakukan pertemuan orang-perorang dan membentuk kelompok untuk melakukan kerjasama, berinteraksi untuk mencapai tujuan bersama. Usaha penambangan 
pasir sebagai mata pencaharian masyarakat sekitar Sungai Padang membawa pengaruh berupa perubahan lingkungan terutama bagi kondisi sosial ekonomi masyarakat Di Desa Naga Kesiangan.

\section{METODE}

Jenis penelitian yang digunakan adalah deskriptif korelasional. Secara sederhana, korelasi dapat diartikan sebagai hubungan. Namun ketika dikembangkan lebih jauh, korelasi tidak hanya dapat dipahami sebatas pengertian tersebut. Korelasi merupakan salah satu teknik analisis dalam statistik yang digunakan untuk mencari hubungan antara dua variabel yang bersifat kuantitatif.

Teknik Pengumpulan data yang penulis gunakan adalah :

1.Observasi (Pengamatan)

Observasi yang digunakan oleh peneliti adalah observasi maka peneliti nonpartisipan dimana peneliti tidak terlibat dan hanya datang sebagai pengamat langsung . Peneliti mengamati tentang ketersediaan pasir, model penambangan pasir dan dampaknya bagi kondisi sosial ekonomi masyarakat di
Desa Naga Kesiangan Kabupaten Serdang Bedagai.

2. Dokumentasi

Metode ini digunakan untuk mengumpulkan data yang sudah ada dalam catatan dokumen yang digunakan sebagai data pendukung dan pelengkap dari data primer yang diperoleh dari observasi dan wawancara Peneliti melakukan dokumentasi dengan cara catatan tulisan,foto, recording, dan mencari data-data yang sudah tercatat seperti gambaran umum Desa Naga Kesiangan berupa geografis, demografis,ekonomi, sosial dan budaya. Dokumentasi dilakukan sejak observasi lapangan hingga turun ke lokasi penelitian.

3. Angket

Angket yang disebarkan digunakan untuk mendapatkan data tentang pengaruh aktivitas penambangan pasir terhadap kondisi sosial ekonomi masyarakat di Desa Naga Kesiangan. Analisis data adalah proses penguraian data, menyusun dan mengkategorikan, mencari pola atau tema dengan maksud untuk memahami. Teknik analisis yang digunakan dalam penelitian ini adalah teknik analisis data kuantitatif. 
Teknik analisis data dalam penelitian kuantitatif menggunakan statistik.Oleh karena itu penelitian ini menggunakan statistik deskriptif karena dapat digunakan bila peneliti ingin mendeskripsikan data sampel. Untuk itu peneliti menggunakan analisis terhadap jawaban responden dengan presentasi $\mathrm{Y}=\mathrm{a}+\mathrm{bX}$

Berikut rumus untuk mencari nilai a dan b:

$$
\begin{aligned}
a & =\frac{\left(\sum Y\right)\left(\sum X^{2}\right)-\left(\sum X\right)\left(\sum X Y\right)}{(n)\left(\sum X^{2}\right)-\left(\sum X\right)^{2}} \\
b & =\frac{n\left(\sum X Y\right)-\left(\sum X\right)\left(\sum Y\right)}{(n)\left(\sum X^{2}\right)-\left(\sum X\right)^{2}}
\end{aligned}
$$

Keterangan:

Y : Variabel terikat (hasil belajar)

X : Variabel bebas (model pembelajaran)

a : Intersep (nilai $Y$, bila $\mathrm{X}=\mathrm{o}$ )

b : Koefisien regresi/slop (kemiringan garis regresi)

n : Jumlah data

Lokasi penelitian merupakan tempat yang akan dijadikan untuk penelitian, dalam hal ini lokasi penelitian adalah Desa Naga Kesiangan.
Pelaksanaan penelitian yang direncanakan peneliti mulai dari bulan Februari sampai April.

\section{HASIL DAN PEMBAHASAN}

Di bawah ini merupakan analisis data secara statistik untuk menjawab pertanyaan-pertanyaan penelitian. Tujuan dari penelitian ini adalah untuk mengetahui :

1. Tingkat aktivitas penambangan pasir di Desa Naga Kesiangan.

2. Seberapa besar status sosial ekonomi masyarakat Desa Naga Kesiangan.

3. Untuk mengetahui seberapa besar pengaruh aktivitas penambangan pasir terhadap tingkat sosial ekonomi masyarakat Desa Naga Kesiangan.

Berikut ini adalah hasil penelitian yang dilakukan untuk menjawab pertanyaan-pertanyaan penelitian.

\section{Tingkat Aktivitas Penambangan Pasir} Di Desa Naga Kesiangan

Adapun untuk menentukan kategori berat, sedang dan ringannya aktivitas penambangan pasir dapat dilihat dari uraian sebagai berikut : 
Nilai Maksimum $=28$

Nilai Minimum $=17$

Range $28-17=11$

Interval $11: 3=3,6$

Berdasarkan perhitungan statistika tersebut, maka diperoleh interval Aktivitas Penambangan Pasir. Hasilnya dapat dilihat dalam tabel berikut :

\begin{tabular}{|c|c|c|c|}
\hline Aspek & Kategori & Frekuensi & Presentase \\
\hline \multirow{3}{*}{ Aktivitas } & Sering & 53 & 72,22 \\
\cline { 2 - 4 } & Kadang & 16 & 22,22 \\
\cline { 2 - 4 } Penambangan & Jarang & 4 & 5,56 \\
\cline { 2 - 4 } Pasir & Jumlah & 73 & 100 \\
\cline { 2 - 4 } & & & \\
\hline
\end{tabular}

Jika digambarkan dengan grafik, maka aktivitas penambangan pasir akan nampak sebagai berikut :

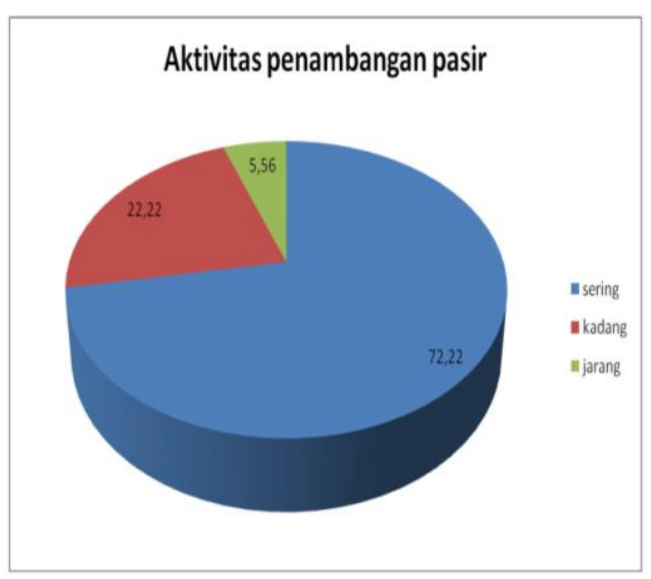

Tabel dan grafik di atas menjelaskan aktivitas penambangan pasir, dari tabel dan grafik tersebut dapat diperoleh informasi bahwa sebagian besar $(72,22 \%)$ reponden melakukan aktivitas penambangan pasir dengan kategori Sering. Sedangkan responden yang memiliki kategori kadang sebanyak $(\mathbf{2 2 , 2 2} \%)$, dan responden dengan kategori jarang sebanyak (5,56\%). Maka rata-rata responden di Desa Naga Kesiangan melakukan aktivitas penambangan pasir kategori sering $(\mathbf{7 2}, 22 \%)$ yang dimaksud dengan kategori sering karena aktivitas penambangan pasir di Desa Naga Kesiangan dilakukan dalam seminggu mereka dapat bekerja selama 6 hari kerja maka dari itu aktivitas penambangan pasir tergolong kategori sering dengan skor rata-rata 24,06.

\section{Status Sosial Ekonomi Masyarakat Desa Naga Kesiangan}

Di bawah ini akan dipaparkan perhitungan statistik status sosial ekonomi di Desa Naga Kesiangan yang dibagi ke dalam lima faktor, yaitu faktor pendidikan, kondisi tempat tinggal, tingkat pendapatan, tingkat kekayaan, dan kesehatan. Yang pertama akan dibahas ialah faktor pendidikan dan selanjutnya faktor-faktor berikutnya.

\section{Faktor Pendidikan}

Adapun untuk menentukan kategori tinggi, sedang dan rendahnya 
faktor pendidikan dapat dilihat dari ekonomi dari pendidikan dengan uraian sebagai berikut :

$\begin{array}{ll}\text { Nilai Maksimum } & =37 \\ \text { Nilai Minimum } & =19 \\ \text { Range } 37-19 & =18 \\ \text { Interval } 18: 3 & =6\end{array}$

Hasilnya dapat dilihat dalam tabel berikut :

\begin{tabular}{|c|c|c|c|}
\hline Aspek & Kategori & Frekuensi & Presentase \\
\hline \multirow{3}{*}{ Pendidikan } & PT & 22 & 30,6 \\
\cline { 2 - 4 } & SMA & 37 & 50 \\
\cline { 2 - 4 } & SMP & 13 & 17,4 \\
\cline { 2 - 4 } & SD & 1 & 2 \\
\cline { 2 - 4 } & Jumlah & 73 & 100 \\
\hline
\end{tabular}

Jika digambarkan dengan grafik, maka faktor pendidikan akan nampak sebagai berikut :

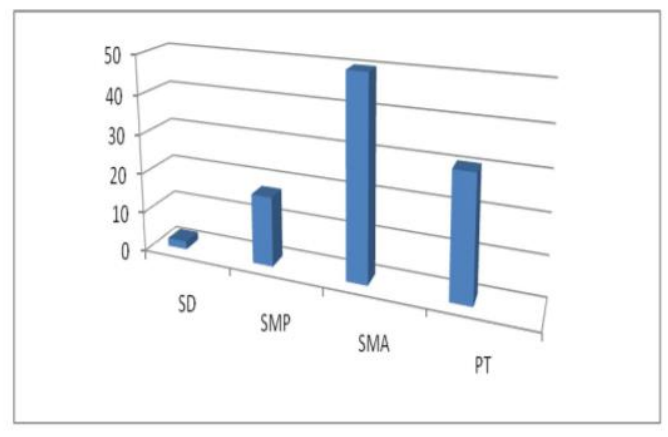

Tabel dan grafik di atas menjelaskan kategorisasi faktor pendidikan, dari tabel dan grafik tersebut dapat diperoleh informasi bahwa setengah (50\%) dari responden memiliki status sosial kategori SMA. Sedangkan responden dengan kategori PT sebanyak (30,6\%), dengan kategori SMP sebanyak $(17,4 \%)$ dan kategori SD (2\%). Maka rata-rata responden di Desa Naga Kesiangan memiliki status sosial ekonomi pendidikan kategori SMA (50\%) dengan skor rata-rata 29,05 .

\section{Faktor Kondisi Tempat Tinggal}

Adapun untuk menentukan Sangat layak, layak dan tidak layak faktor kondisi tempat tinggal dapat dilihat dari uraian sebagai berikut :

Nilai Maksimum = 37

Nilai Minimum $=19$

Range $37-19=18$

Interval $18: 3=6$

Selanjutnya Jawaban responden terhadap faktor kondisi tempat tinggal diklasifikasi berdasarkan perhitungan frekuensi dan presentase. Hasilnya dapat dilihat dalam tabel berikut:

\begin{tabular}{|c|c|c|c|}
\hline Aspek & Kategori & Frekuensi & Presentase \\
\hline \multirow{3}{*}{ Kondisi Tempat } & Sangat Baik & 23 & 31,6 \\
\cline { 2 - 4 } Tinggal & Baik & 37 & 50 \\
\cline { 2 - 4 } & Kurang Baik & 13 & 18,4 \\
\cline { 2 - 4 } & Jumlah & 73 & 100 \\
\hline \multicolumn{3}{|c|}{ Sumber: Hasil olah data penulis } \\
\hline
\end{tabular}

\section{Page | 16}

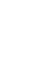


Jika digambarkan dengan grafik, maka faktor kondisi tempat tinggal akan nampak sebagai berikut :

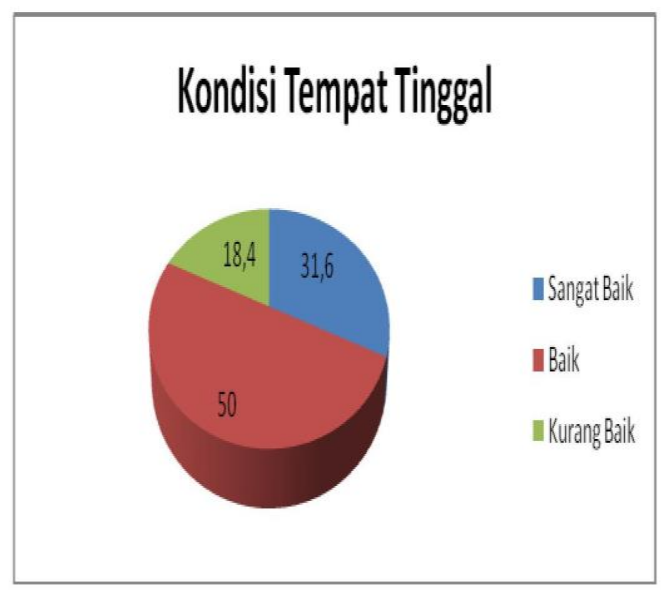

Tabel dan grafik di atas menjelaskan kategorisasi faktor kondisi tempat tinggal, dari tabel dan grafik tersebut dapat diperoleh informasi bahwa setengah (50\%) dari responden memiliki status sosial ekonomi dari kondisi tempat tinggal dengan kategori Baik. Sedangkan responden dengan kategori sangat baik (31,6\%), dan kategori kurang baik sebanyak (18,4\%). Maka rata-rata responden di Desa Naga Kesiangan memiliki status sosial ekonomi kondisi tempat tinggal kategori baik (50\%) dengan skor rata-rata 29,05. Kategori Rumah yang Sangat Baik berdasarkan jenis dan bahan bangunan dengan kualitas terbaik yaitu rumah yang sudah berdinding beton dengan atap memakai Genteng alumunium terbaik dan lantai sudah berkramik Disertai Dengan Jendela untuk sirkulasi udara yang baik pada rumah. Sedangkan Kegori rumah yang Baik yaitu dinding batu bata dan dilapisin semen, serta atap yang terbuat dari Seng multirum dan lantai yang sudah dikramik. Dan rumah kategori kurang baik yaitu rumah yang berdinding setengah batu bata dan papan, serta atap yang terbuat dari seng biasa dan lantai yang masih semen/belum dikramik.

\section{Faktor Pendapatan}

Adapun untuk menentukan kategori tinggi, sedang dan rendahnya faktor pendapatan dapat dilihat dari uraian sebagai berikut :

$\begin{array}{ll}\text { Nilai Maksimum } & =18 \\ \text { Nilai Minimum } & =12 \\ \text { Range } & =18-12=6 \\ \text { Interval } & =6: 3=2\end{array}$

Selanjutnya Jawaban responden terhadap faktor pendapatan diklasifikasi berdasarkan perhitungan frekuensi dan presentase. Hasilnya dapat dilihat dalam tabel berikut :

\section{Page $\mid 17$}

\section{(n)}




\begin{tabular}{|c|c|c|c|}
\hline Aspek & Katecoori & Frektuensi & Presentase \\
\hline \multirow{4}{*}{ Pendapatan } & Timgog & 37 & 47,22 \\
\hline & Seldangy & 22 & 27,78 \\
\hline & Rendah & 14 & 25 \\
\hline & Jumlah & 73 & 100 \\
\hline
\end{tabular}

Jika digambarkan dengan grafik, maka faktor kondisi tempat tinggal akan nampak sebagai berikut :

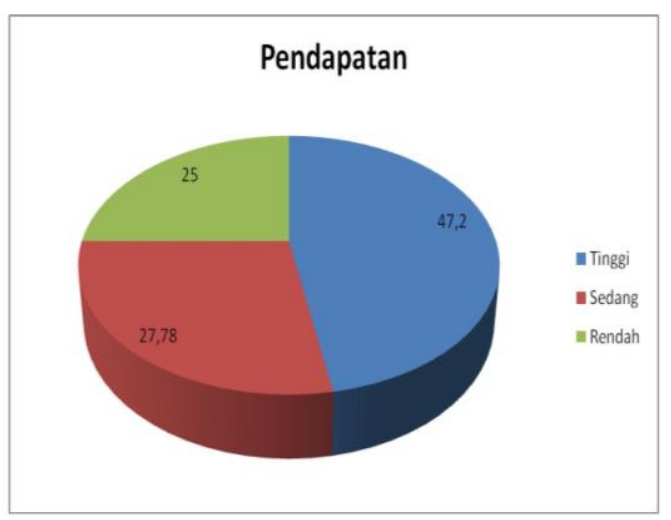

Tabel dan grafik di atas menjelaskan kategorisasi faktor pendapatan, dari tabel dan grafik tersebut dapat diperoleh informasi bahwa hampir setengah (47,22\%) dari responden memiliki status sosial ekonomi dari pendapatan dengan kategori tinggi. Sedangkan responden dengan kategori sedang sebanyak (27,78\%), dan dengan kategori rendah sebanyak (25\%). Maka rata-rata responden di Desa Naga Kesiangan memiliki status sosial ekonomi dari pendapatan dengan kategori sedang (47,22\%) dengan skor rata-rata 16,1. Page | 18 Berdasarkan kategori Tinggi, Sedang, dan Rendah Pendapatan masyarakat dilihat dari berapa pendapatan masyarakat perbulannya, adapun pendapatan masyarakat Di Desa Naga Kesiangan adalah Sebagai berikut :

a. Tinggi, jika pendapatan responden $>\mathrm{Rp}$ 3.500.00o,/bulan

b. Rendah, jika pendapatan responden $<\mathrm{Rp}$. 3.000.0oo,/bulan

\section{Faktor Kekayaan}

Adapun untuk menentukan kategori tinggi, sedang dan rendahnya faktor kekayaan dapat dilihat dari uraian sebagai berikut :

$\begin{array}{ll}\text { Nilai Maksimum } & =5 \\ \text { Nilai Minimum } & =2 \\ \text { Range } & =5-2=3 \\ \text { Interval } & =3: 3=1\end{array}$

Hasilnya dapat dilihat dalam tabel berikut : 


\begin{tabular}{|c|c|c|c|}
\hline Aspek & Kategoori & Frekuensi & Presentase \\
\hline \multirow{4}{*}{ Kekajaan } & Kaya & 29 & 40 \\
\cline { 2 - 4 } & Kurang Kaya & 26 & 35 \\
\cline { 2 - 4 } & Tidakk Kaya & 18 & 25 \\
\cline { 2 - 4 } & Jumlah & 73 & 100 \\
\hline
\end{tabular}

Jika digambarkan dengan grafik, maka faktor kekayaan akan nampak sebagai berikut :

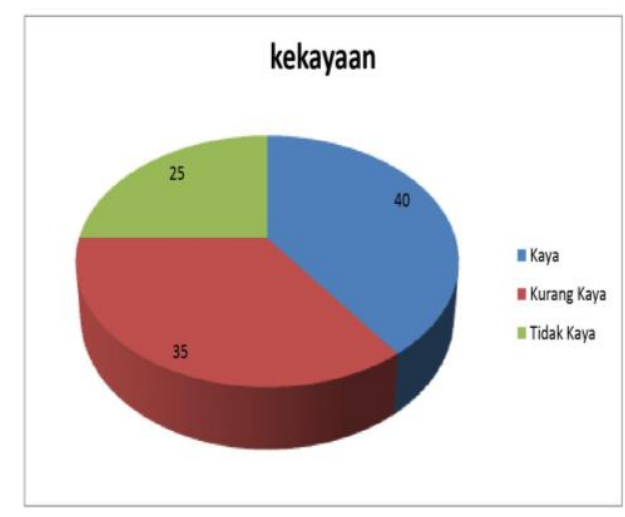

Tabel dan grafik di atas menjelaskan kategorisasi faktor kekayaan, dari tabel dan grafik tersebut dapat diperoleh informasi bahwa (40\%) dari responden memiliki status sosial ekonomi dari kekayaan dengan kategori tinggi. Sedangkan responden dengan kategori sedang sebanyak (35\%), dan kategori rendah sebanyak (25\%). Maka rata-rata responden di Desa Naga Kesiangan memiliki status sosial ekonomi dari kekayaan kategori sedang (40\%) dengan skor rata-rata 4,19. Kekayaan masyarakat Di Desa Naga Kesiangan Dapat dilihat dari harta benda yang mereka miliki, Page $\mid 19$ Seperti :

1. Kaya - Responden memiliki Rumah Pribadi Mewah,Ladang yang luas, Emas dan Tabungan Deposit di Bank

2. Tidak Kaya - Responden tidak memiliki emas, lahan serta rumah pribadi

\section{Faktor Kesehatan}

Adapun untuk menentukan kategori sangat baik, baik dan kurang baik faktor kondisi kesehatan dapat dilihat dari uraian sebagai berikut :

$\begin{array}{ll}\text { Nilai Maksimum } & =35 \\ \text { Nilai Minimum } & =15 \\ \text { Range } & =35-15=\mathbf{2 0} \\ \text { Interval } & =20: 3=6,6\end{array}$

Hasilnya dapat dilihat dalam tabel berikut : 


\begin{tabular}{|c|c|c|c|}
\hline Aspek & Kategori & Frekuensi & Presentase \\
\hline & Sangat Baik & 22 & 30,6 \\
\hline Kesehatan & Baik & 37 & 50 \\
\hline
\end{tabular}

\begin{tabular}{|l|c|c|c|}
\hline \multirow{2}{*}{} & Kurang baik & 14 & 19,4 \\
\cline { 2 - 4 } & Jumlah & 73 & 100 \\
\hline \multicolumn{3}{|c|}{ Sumber : Hasil olah data penulis } \\
\hline
\end{tabular}

Jika digambarkan dengan grafik, maka faktor kesehatan akan nampak sebagai berikut :

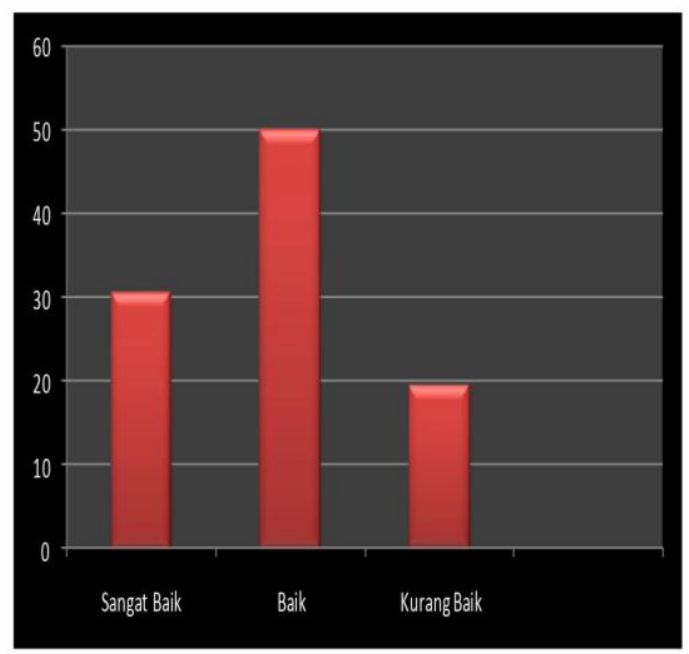

Tabel dan grafik di atas menjelaskan kategorisasi faktor kesehatan, dari tabel dan grafik tersebut dapat diperoleh informasi bahwa setengah (50\%) dari responden memiliki status sosial ekonomi dari kesehatan dengan kategori sedang. Sedangkan responden dengan kategori tinggi sebanyak (30,6\%), dan dengan kategori rendah sebanyak
(19,4\%). Maka rata-rata responden di Desa Naga Kesiangan memiliki status sosial ekonomi kondisi kesehatan kategori sedang (50\%) dengan skor ratarata 31,00.

Karakteristik Kesehatan masyarakat Tergolong Sangat baik, baik, dan kurang baik dapat dilihat dari :

1. Sangat baik Apabila responden dalam setahun tidak ada mengalami gangguan kesehatan yang berat seperti TBC dan osteoporosis.

2. Baik apabila responden dalam setahun hanya mengalami penyakit ringan seperti flu dan keseleo

3. Kurang Baik apabila dalam setahun mengalami penyakit berat seperti TBC dan osteoporosis atau rutin sebulan sekali masuk rumah sakit.

\section{Variabel Status Sosial Ekonomi}

Adapun untuk menentukan kategori tinggi, sedang dan rendahnya variabel status sosial ekonomi dapat dilihat dari uraian sebagai berikut :

$$
\begin{array}{ll}
\text { Nilai Maksimum } & =81 \\
\text { Nilai Minimum } & =64 \\
\text { Range } & =81-64=17 \\
\text { Interval } & =17: 3=5,6
\end{array}
$$


Berdasarkan perhitungan statistika tersebut, maka diperoleh interval pengkategorian variabel status sosial ekonomi sebagai berikut :

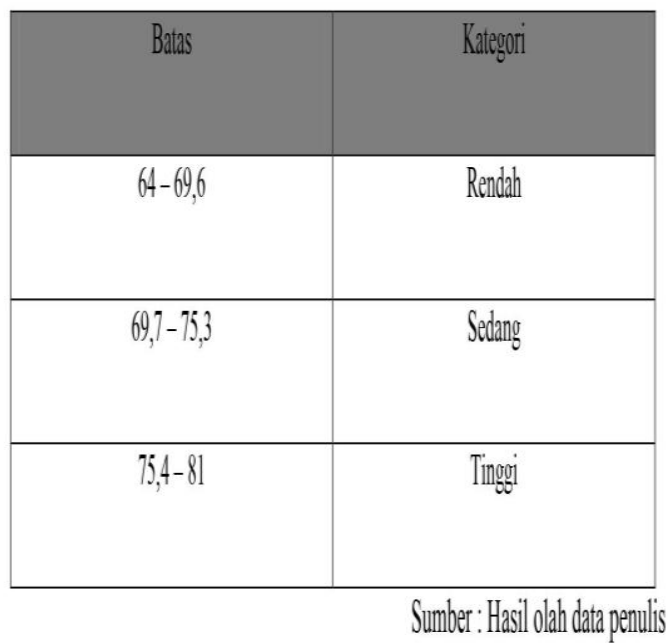

Jika digambarkan dengan grafik, maka gambaran umum mengenai variabel status sosial ekonomi akan nampak sebagai berikut :

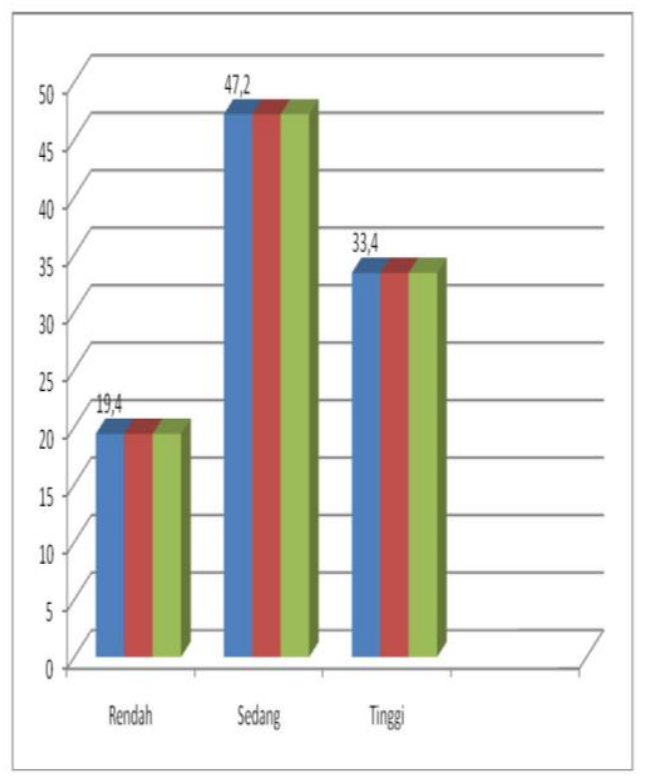

Tabel dan grafik di atas menjelaskan kategorisasi status sosial ekonomi keluarga di Desa Naga Kesiangan, dari tabel dan grafik tersebut dapat dilihat hampir setengah dari responden memiliki status sosial ekonomi dalam kategori sedang sebanyak (47,2\%). Sedangkan hanya sebagian kecil respoden yang memiliki status sosial ekonomi dalam kategori rendah sebanyak (19,4\%), dan responden yang memiliki status sosial ekonomi dalam kategori tinggi sebanyak $(33,4 \%)$. Maka dapat disimpulkan bahwa responden yang bekerja di Penambagan Pasir status sosial ekonomi keluarga yang tergolong sedang $(47,2 \%)$ dengan skor rata-rata 71,78 .

Berdasarkan hasil penelitian mengenai kondisi siosial ekonomi Masyarakat Desa Naga Kesiangan yang dibagi kedalam 5 kategori faktor yang mempengaruhi kondisi sosial ekonomi yaitu pendidikan, kondisi tempat tinggal, pendapatan, kekayaan, dan kesehatan. Hasil penelitian yang pertama pada faktor pendidikan lebih dari setengahnya atau sebagian besar responden memiliki status sosial ekonomi dari pendidikan dalam kategori sedang sebanyak $50 \%$, responden dalam kategori tinggi sebanyak 30,6\%, dan sebagian kecil responden yang dalam kategori rendah sebanyak 19,4\%. Hasil kedua pada faktor 


\section{Journal of Millennial Community, 3 (1), March 2021 \\ Galang Rasidi, Elizon Nainggolan}

kondisi tempat tinggal tepat setengah dari responden memiliki status sosial ekonomi dari kondisi tempat tinggal dengan kategori baik sebanyak $50 \%$, responden dalam kategori sangat baik sebanyak 30,6\%, dan dalam kategori kurang baik sebanyak 19,4\%. Hasil yang ketiga pada faktor pendapatan hampir setengah dari responden memiliki status sosial ekonomi dari pendapatan dalam kategori tinggi sebanyak 47,22\%. Tidak terdapat jauh perbedaan antara responden yang memiliki status sosial ekonomi dari pendapatan dalam kategori sedang dan rendah, responden dalam kategori sedang sebanyak $27,78 \%$, dan responden dalam ketegori rendah sebanyak 25\%. Hasil yang keempat pada faktor kekayaan responden memiliki status sosial ekonomi dilihat dari barangbarang yang mereka miliki (pemilikan) dalam kategori tinggi sebanyak 45\%, responden dalam kategori sedang sebanyak $30 \%$, dan responden dalam kategori rendah hanya sedikit yaitu sebanyak $25 \%$. Hasil Kelima pada faktor kesehatan responden memiliki tingkat kesehatan kategori Sangat Baik Sebesar 30,6\%, dan responden dalam kategori baik sebesar 50\% dan kategori kurang baik sebanyak 19,4 \%. Dari keseluruhan faktor yang mempengaruhi status sosial ekonomi menunjukan bahwa hampir setengahnya $(47,2 \%)$ memiliki status sosial ekonomi sedang, hanya sebagian kecil yang memiliki status sosial ekonomi rendah (19,4\%), dan lebih dari seperempat $(33,4 \%)$ responden yang memiliki status sosial ekonomi tinggi. Dengan skor rata-rata 71,78 . Jadi status sosial ekonomi yang dimiliki masyarakat Desa Naga Kesiangan yang bekerja di Penambangan Pasir dalam sebagian besar dalam kategori sedang sebanyak 47,2\%.

Selanjutnya, hanya sebagian kecil responden yang bekerja di penambangan pasir yang memiliki status sosial ekonomi dalam kategori tinggi (diatas rata-rata) sebanyak 33,4\% itu artinya, responden yang bekerja di penambangan pasir yang masuk ke dalam kategori ini lebih bisa menghidupi dirinya dari kategori yang sebelumnya. Responden yang masuk ke dalam kategori ini kehidupan ekonominya lebih baik diantara yang lain. Keluarga yang masuk ke dalam kategori ini bisa memberikan ilmu pendidikan di sekolah yang lebih tinggi tingkatannya dari yang lainnya. Mereka memiliki barang-barang dirumah yang dapat menunjang kebutuhan sosialnya lebih banyak dibandingkan yang lain. 
Terakhir responden yang bekerja di penambangan pasir dalam kategori status sosial ekonomi rendah sebanyak 19,4\%. Status sosial ekonomi rendah (dibawah rata-rata), artinya mereka yang berada di dalam kategori ini ada dipaling bawah diantara kategori yang lainnya. Mereka tidak dapat memilih untuk melanjutkan pendidikannya, karena mereka diharuskan untuk bekerja keras membantu kebutuhan keluarganya

\section{KESIMPULAN}

Aktivitas Penambangan Pasir di Desa Naga Kesiangan sebagian besar termasuk dalam kategori Sering 72,22\%.. Hal ini dapat dilihat dari rata rata lamanya waktu bekerja baik waktu kerja dalam sehari maupun dalam seminggu serta dari alat yang digunakan. Rata rata penambang bekerja 10 jam/hari dan 5-6 hari/minggu. Selain itu masih menggunakan alat tradisional yakni sekop untuk membongkar muat pasir. Kondisi sosial ekonomi masyarakat di Desa Naga Kesiangan Sebagian besar termasuk dalam kategori sedang (47,2\%). Pengaruh pertambangan pasir terhadap kondisi sosial ekonomi masyarakat Desa Naga Kesiangan :

\section{DAFTAR PUSTAKA}

Badan Pusat Statistik, 2010. Indikator Kesejahteraan Rakyat. BPS Jakarta-Indonesia.

Sumardi. 2004. Pendapatan Ekonomi Page | 23 Rumah Tangga. Jakarta: Rineka Cipta.

Mankiw, N Greegory. 200o. Teori Ekonomi Makro.Jakarta: Salemba Empat

Sugiyono, 2013. Metode Penelitian Pendidikan Pendekatan Kuantitatif, kualitatif, dan RED, Penerbit Alfabeta, Bandung.

Aziz.Arnicun.(2001). IlmuSosial Dasar. Jakarta: PT Raja Grafindo.

Muhammad Bima Sakti, Achmad Maulana Malik Jamil, Ika Meviana, 2019 Pengaruh Pertambangan Marmer Terhadap Kondisi Sosial Ekonomi Masyarakat Desa Besole Kecamatan Besuki Kabupaten Tulungagung. Online:

http://ejournal.unikama.ac.id Lindex.php/JPIG/

Basrowi 2010 Analisis Kondisi Sosial Ekonomi Dan Tingkat Pendidikan Masyarakat Desa Srigading, Kecamatan Labuhan Maringgai, Kabupaten Lampung Timur.http://ejournal.unila.ac .id/index.php/JPIG/ 


\section{Journal of Millennial Community, 3 (1), March 2021 \\ Galang Rasidi, Elizon Nainggolan}

\section{PROFIL SINGKAT}

Penulis pertama, Galang Rasidi, merupakan mahasiswa program studi Pendidikan masyarakat Universitas Negeri Medan. Penulis kedua, Elizon Nainggolan merupakan dosen program studi Pendidikan masyarakat Universitas Negeri Medan. 